\title{
О.П. Гудима
}

\author{
Центр воєнно-стратегічних досліджень \\ Національного університету оборони України ім. I. Черняховського, Київ
}

\section{МІЖНАРОДНИЙ ДОСВІД ПОБУДОВИ СИСТЕМ ЗАБЕЗПЕЧЕННЯ НАЦІОНАЛЬНОЇ БЕЗПЕКИ. ВИСНОВКИ ДЛЯ УКРАЇНИ}

На протязі 30 років назалежності України тривають роботи щуодо побудови системи забезпечення національної безпеки держави (сектору безпеки і оборони, сил оборони). 3 виданням нової редакції Закону України “Про національну безпеку України” змінилась структура керівних документів держави. На сьогоднішній день триває етап опрацювання відповідних нормативних документів центральними органами виконавчої влади, які виконують завдання в сфері національної безпеки і оборони. При формуванні нормативноправової бази держави дочільно врахувати досвід побудови систем забезпечення начіональної безпеки краӥн світу. В статті проаналізовано досвід Сполучених Штатів Америки, Канади, країн Європи, Китайської народної республіки, Туреччини, Японії, Південної Кореї. На основі проаналізованого досвіду опрацьовані пропозицї щзодо удосконалення системи забезпечення національної безпеки України (сектору безпеки і оборони, сил оборони) та державної системи управління силами оборони в кризових ситуаціях.

Ключові слова: начіональна безпека, нормативно-правова база, сили оборони, міжнародний досвід, державна система управління.

\section{Вступ}

Постановка проблеми. Видання в новій редакції Закону України "Про національну безпеку України” та Указу Президента України "Про рішення Ради національної безпеки і оборони України від 14 вересня 2020 року “Про Стратегію національної безпеки України” дозволило розпочати концептуальне оновлення та правове врегулювання діяльності в сфері національної безпеки і оборони України та створило умови для побудови дієвої вертикалі управління сектором безпеки і оборони (СБіО) та безпосередньо силами оборони (СО).

В свою чергу Указ Президента України “Про рішення Ради національної безпеки і оборони України від 25 березня 2021 року “Про Стратегію воєнної безпеки України” дозволив опрацювати бачення, виходячи 3 реалій сьогодення, щодо побудови, підготовки та всебічного забезпечення всеохоплюючої оборони України на засадах стримування, стійкості та взаємодії.

На сьогоднішній день триває етап опрацювання відповідних нормативних документів центральними органами виконавчої влади, які виконують завдання в сфері національної безпеки і оборони. При формуванні нормативно-правової бази держави доцільно врахувати досвід побудови систем національної безпеки країн світу.

В даній статті буде проведено комплексний аналіз досвіду країн світу при побудові систем національної безпеки та опрацювання рекомендацій щодо удосконалення вітчизняного СБіО, СО та державної системи управління СО України.
Аналіз останніх досліджень і публікацій. В [1] авторами проведено аналіз досвіду та окреслено систему суб'єктів публічного адміністрування США в сфері національної безпеки. В [2] автором розглянуто погляди на функціонування інститутів (законодавчі аспекти управління національною безпекою за кордоном), що безпосередньо відповідають за координацію систем національної безпеки і можуть брати на себе відповідні повноваження в кризові періоди в таких країнах, як США, Велика Британія, Туреччина, Республіка Польща (РП). В [3] авторами проаналізовано досвід Європейського Союзу (ЄС) щодо створення та функціонування спільної системи європейської безпеки, а також досвід РП та США щодо реформування та розвитку систем забезпечення національної безпеки. Запропоновані шляхи удосконалення законодавчого забезпечення, запровадження системи стратегічного планування і прогнозування, тощо. В [4] автором висвітлено питання щодо адміністрування національної безпеки й обороноздатності у таких зарубіжних державах, як: Японія, Китайська народна республіка (КНР), Південна Корея. В [5] авторами висвітлюється практика публічно-правового забезпечення національної безпеки у провідних країнах Свропи та США, іï принципи та головні напрями удосконалення. В [6] авторами праналізовано інформаційно-аналітичні засоби забезпечення державного управління у провідних країнах світу та досвід створення ситуаційних центрів (СЦ) (США, СС, Федеративна республіка Німеччина, КНР, Сінгапур, Бразилія, Російська Федерація). 
В [7] автором розглянуто питання покращення якості управлінських рішень 3 залученням до системи державного управління додаткових спеціальних організаційно-технічних комплексів - СЦ.

В статті розглянуто національний досвід (в період 31962 року до сьогодення) щодо створення СЦ (кризових центрів, інформаційно-аналітичних центрів). Висвітлено перелік основних керівних документів держави щодо побудови відповідних СЦ, основних виконавців проведених робіт. Сформовано пропозиції щодо удосконалення побудови мережі СЦ.

В [8] автором розглянуто аспекти гібридної війни. Враховуючи досвід провідних країн світу 3 протидії гібридним загрозам та відповідно до завдань визначених керівними документами держави запропоновано побудувати державну систему управління (координації) заходів протидії гібридним загрозам на базі системи СЦ.

В [9] авторами розглянуто основні аспекти створення ефективної державної системи кризового реагування (мережі СЦ центральних органів виконавчої влади). Визначено основні напрямки удосконалення, підвищення ефективності та якості управлінських рішень щодо забезпечення національної безпеки України.

Поряд 3 цим, в вище зазначених роботах аналізується досвід країн світу щодо побудови систем забезпечення національної безпеки, та опрацьовується питання що стосується удосконалення законодавчого забезпечення сфери національної безпеки і оборони України, а питання функціонального наповнення складових СБіО (СО) і особливості управління та координації виходячи 3 досвіду країн світу не розглядається, що і обумовлює актуальність роботи.

Мета статті - комплексний аналіз міжнародного досвіду побудови систем забезпечення національної безпеки. Вироблення пропозицій щодо удосконалення системи національної безпеки і оборони України, СБіО, СО.

\section{Виклад основного матеріалу}

Розглянемо досвід країн світу щодо створення систем забезпечення національної безпеки (СЗНБ) використовуючи метод кейс-стаді (з англ. case-study - вивчення ситуаціі).

Що стосується США. Зважаючи на те, що за формою державного правління США - президентська республіка, глава держави (як керівник виконавчої влади і Верховний головнокомандувач Збройними силами) на сьогодні є ключовою ланкою у СЗНБ на стратегічному рівні $[1 ; 3]$.

Сучасна СЗНБ США має дуже складну і дорогу структуру. У неї входять: Президент США, радники Президента США, виконавчий апарат, міністерства і відомства, Конгрес. Неформальними учасниками системи забезпечення національної безпеки США $€$ засоби масової інформації [1].

Виконавчий апарат Президента здійснює реалізацію поставлених завдань, до складу якого входить Бюро Білого дому в складі близько 400 осіб [11].

У центрі СЗНБ США стоїть Рада національної безпеки (РНБ), яка є підрозділом Виконавчого офісу (Адміністрації) президента США. Вона діє під головуванням президента та керівництвом радника президента 3 питань національної безпеки (секретаря РНБ) і виступає координуючим та контролюючим органом, куди інкорпоровані представники всіх відповідальних агентств та установ. РНБ пропонує президентові варіанти рішень, які пізніше лягають в основу політики в галузі національної безпеки [1-3].

Функції РНБ (National Security Council) - “надавати поради президентові щодо внутрішньої, міжнародної та воєнної політики, які належать до сфери національної безпеки, а також сприяти ефективній кооперації військових служб та управлінь в уряді щодо питань національної безпеки”. У законі дуже чітко розписано структуру РНБ, функції та відповідальність кожного з відділів, причому йдеться про досить конкретні визначення [2].

Основні функції цей орган здійснює на рівні свого апарату. РНБ може не збиратися протягом тривалого часу [10].

Після терористичного акту в м. Нью-Йорк 9 вересня 2001 р. Дж. Буш видав виконавчий наказ № 13228, який поклав початок формуванню нової організаційної структури, покликаної забезпечувати безпеку країни і суспільства додатково до вже існуючої системи забезпечення національної безпеки США [1].

У жовтні 2001 р. прийнято Закон "Про боротьбу з тероризмом”, в якому розширено повноваження спецслужб, спрощено процедуру отримання правоохоронними органами санкції суду на прослуховування розмов потенційних екстремістів і пов'язаних 3 ними осіб, на проведення обшуків. На підставі Указу Президента від 13 листопада 2001 р. “Про затримання, обіг і розгляд справ щодо негромадян в ході війни з тероризмом" справи про міжнародний тероризм розглядають спеціальні комісії (військові комісії), а рішення приймає Президент або Міністр оборони. Нова організаційна структура, відповідно до поставлених завдань, отримала назву системи внутрішньої безпеки [1].

Найчисленнішою установою в структурі служби забезпечення національної безпеки США є Міністерство оборони, створене спочатку в 1947 р. як національне військове відомство, потім в 1949 р. як Міністерство оборони США [1; 12]. Міністр оборони, будучи головним помічником Президента з усіх питань оборони країни, здійснює контроль над апаратом міністра, Комітетом начальників штабів і мі- 
ністерством видів збройних сил. [1].

Головною структурою в РНБ США є Національне розвідувальне співтовариство США, яке налічує понад 150 тис. співробітників. Його головна функція полягає в забезпеченні керівництва країни достовірною інформацією для вирішення завдань зовнішньої політики, використання збройних сил, прийняття рішень в кризових ситуаціях, керівництва збройними силами. До структури розвідувального співтовариства входять: Центральне розвідувальне управління, Розвідувальне управління Міністерства оборони і Управління національної безпеки; розвідувальні сектора Державного департаменту, Міністерства юстиції, енергетики та казначейства; Національна розвідувальна служба і Центральний офіс 3 іміджу [1].

Однак, після терористичного акту в 2001 році почала формуватися нова організаційна структура Система внутрішньої безпеки, що складається з Ради внутрішньої безпеки і Служби внутрішньої безпеки. Статус новоствореної ради передбачалося зробити таким же високим як статус РНБ, оскільки ії членами є всі вищі посадові особи, які представляють виконавчу гілку влади [1].

На жаль, не існує чіткої межі між повноваженнями РНБ США і Ради внутрішньої безпеки, оскільки, по-перше, в жодному нормативному акті США не визначено, що мається на увазі під “національною безпекою"; по-друге, повноваження РНБ визначені в Законі “Про національну безпеку", а статус Ради внутрішньої безпеки існує лише на рівні підзаконного нормативного акта. Службу внутрішньої безпеки створили, як координуючий центр, що розробляє і реалізує загальнонаціональну стратегію в сфері захисту США від терористичних загроз. Таким чином, видно, що рішення про створення нових органів носить переважно спонтанний і вимушений характер перед обличчям терористичної загрози [1].

У листопаді 2002 р. було створено Міністерство внутрішньої безпеки чисельністю близько 170 тис. осіб як найважливіший орган виконавчої влади для вирішення завдань щодо запобігання терористичним актам в США. Очолює його міністр внутрішньої безпеки, який призначається Президентом 3 числа цивільних осіб і затверджується сенатом Конгресу США [1].

Міністерство складається 3 чотирьох директорів: аналізу інформації та захисту інфраструктури; безпеки кордонів і транспорту; надзвичайної готовності і реагування; науки і технології [1; 13]. У Мiністерство були переведені підрозділи інших міністерств: з Міністерства фінансів - секретна спецслужба, що здійснює охорону вищих осіб держави; Митна служба; з Міністерства транспорту - Служба берегової охорони; Адміністрація з безпеки на транспорті [1].
Незважаючи на наміри політичного керівництва США таким шляхом вирішити питання щодо поліпшення координації елементів СЗНБ, МВБ не $є$ достатньо ефективною структурою через роздутість штату (майже 240 тис. співробітників) та надмірну забюрократизованість. Діяльність МВБ також постійно піддається критиці за намагання встановити тотальний контроль над суспільством та значні витрати бюджетних коштів [3].

США здійснюють заходи щодо створення системи органів, яку умовно можна диференціювати на дві складові: органи, що спеціалізуються на проведенні наступальної політики, спрямованої на забезпечення національних інтересів США в світі; органи, спрямовані на забезпечення внутрішньої безпеки США. У сукупності ці два складники повинні утворити єдину СЗНБ США із загальною метою створення умов для розвитку [1].

Що стосується Канади. Після подій 11 вересня 2001 р. відбулися зміни в системі інститутів національної безпеки. У Канаді утворили нове відомство, яке мало опікуватись внутрішньою безпекою - Miністерство державної (публічної) безпеки та готовності до надзвичайних ситуацій (Department of Public Safety and Emergency Preparedness). До цього відомства увійшла Канадська секретна служба розвідки, що є основною спецслужбою країни. Однак наявність у нього спеціальних елементів не надає йому правоохоронних функцій. В основі лежить дуже специфічне і навряд чи доречне, крім Північної Америки, поєднання структур, які відповідають за захист від надзвичайних ситуацій та діяльність міграційних служб [10].

У Канаді, яку вважають еталоном відкритого демократичного суспільства, цивільна розвідка і контррозвідка поєднані в єдиній структурі, позбавленій втім правоохоронних повноважень [10]

Міністерство внутрішньої безпеки США та аналогічна структура в Канаді засновані для уникнення, а в разі неможливості - вчасного й ефективного реагування на надзвичайні ситуації, спричинені передусім терористичними угрупованнями. Цим визначається і склад цих структур. Завдання цих утворень такі [10]:

- недопущення проникнення в країну терористичних груп;

- захист інфраструктури;

- швидка ліквідація наслідків терористичних нападів, якщо їх не вдасться відвернути, а також техногенних та екологічних катастроф, не пов'язаних з чиїмось злим наміром.

До нових інтегральних структур внутрішньої безпеки долучені деякі спецслужби (без правоохоронних повноважень щодо цивільного населення), завданням яких є насамперед інформаційне забезпечення [10]. 
Спрямованість реформ у секторах безпеки і оборони США та Канади полягає у забезпеченні збереження дієвості демократичних інститутів в умовах надзвичайних ситуацій. Більше того, у США і Канаді демократія вважається основним рецептом захисту від внутрішнього екстремізму, а отже запобіжником широкому спектру внутрішніх загроз [10].

Що стосується країн СС. Визначальним фактором, гарантом національного суверенітету й протидії зовнішнім загрозам для країн-членів СС залишається воєнно-політичний блок НАТО, до складу якого входять майже всі держави ЄС. Американська військова присутність на континенті, а особливо ядерна складова Альянсу, виступають гарантом європейської безпеки [3; 14]. Разом з тим, необхідність протидії новим глобальним загрозам (насамперед, тероризму, релігійному екстремізму й сепаратизму) зумовила формування Спільної зовнішньої та безпекової політики (СЗБП), початок чому поклав Маастрихтський договір, підписаний у лютому 1992 р. СЗБП як один із трьох “стовпів”, на яких тримається СС, мала вирішувати наступні завдання [3; 15]:

- захист спільних цінностей відповідно до Статуту ООН; зміцнення безпеки $\mathrm{CC}$; збереження миру та міжнародної безпеки; підвищення одноосібної ролі ЄС у визначенні спільної зовнішньої політики; створення структури з планування нової політики та завчасного попередження з метою аналізу міжнародних подій і опрацювання рішень; запровадження посади Верховного представника з питань СЗБП.

3 метою більш широкого охоплення військових аспектів та кризових ситуацій, у 1999 р. СЗБП була доповнена Свропейською безпековою та оборонною політикою (СПБО), яку у 2009 р. перейменували у Спільну безпекову та оборонну політику (СПБО) [3].

Формально СБОП перебуває у компетенції Свропейської ради, але фактичним координатором діяльності у рамках обох згаданих політик є Верховний представник з питань СЗБП, який крім цього обіймає ще кілька важливих посад: віце-президент Європейської комісії; президент Ради міністрів закордонних справ $Є С$; керівник Європейської служби зовнішньополітичної діяльності (ЄСЗД); президент Європейського оборонного агентства; голова правління Інституту ЄС 3 досліджень безпеки [16].

В Свропі застосовується принцип організаційного розмежування. У Великій Британії та Німеччині цивільна контррозвідка здійснюється через організаційну взаємодію винятково спеціальних і правоохоронних структур, тобто спеціальні й правоохоронні функції взагалі не перетинаються в одній силовій структурі [10].

В європейській системі цивільна розвідка належить до компетенції виконавчої влади. Наприклад, у Великій Британії - це спеціалізована агенція міністерства закордонних справ. Цивільна контр- розвідка належить до міністерства внутрішніх справ, Але позбавлена правоохоронних функцій, тобто не має права затримувати, вести досудове слідство, проводити дізнання. У свою чергу, правоохоронні органи Великої Британії (Scotland Yard) обмежені у спеціальних повноваженнях, таких як приховане збирання інформації й агентурна робота [10].

У європейських країнах система керівництва сектором оборони пов'язана насамперед із питаннями створення централізованого стратегічного керівництва ним, що дає змогу підвищити якість прийняття рішень. Важливою формою інтеграції $є$ створення центрів оцінювання загроз. Їх основною функцією є моніторинг ситуації на основі інформації 3 усіх джерел, наявних у держави, оцінювання на іiі основі рівня загроз, відповідно до якого мають діяти органи державної управління сектором безпеки i оборони, встановлення ступеня готовності відповідних складових до реагування на кризові ситуації $[10 ; 17]$.

Спільною рисою європейських країн у питаннях вдосконалення стратегічного керівництва сектором безпеки і оборони є наділення глави держави функціями верховного головнокомандувача, крім Нідерландів, Німеччини і Швеції, де за конституцією такі повноваження закріплені за урядом [10].

Що стосується Великої Британії. Ця типово парламентська держава випрацювала власний тип управління безпекою, який дуже відрізняється від тих, що діють у країнах з сильною президентською владою. Його суть - у розпорошенні завдань і функцій, а також відповідальності по різних структурах і управліннях. Причому існує значна кількість надвідомчих рад і комітетів, які не перетинаються одне 3 одним, але забезпечують загальне функціонування системи національної безпеки. Очевидно, одна 3 причин цього - багатовікова історія англійського парламентаризму, протягом якої вдалося випрацювати ефективні зв'язки і формули [2].

У Великій Британії система управління національною безпекою має назву “механізми національної безпеки" або "механізми національної розвідки" (National Security Machinery or National Intelligence Machinery) [2; 18]. Прем'єр-міністр країни відповідає за весь механізм безпеки. В цьому його дорадником $€$ координатор $з$ питань безпеки і розвідки, який координує діяльність різних агенцій. Міністри відповідають за безпеку у своїх секторах [2].

Існують окремі структури для координації безпеки в різних галузях. Так, для захисту інформаційних баз даних 1999 року створено Центр з координації безпеки національної інфраструктури (National Infrastructure Security Coordination Centre) - для проведення міжвідомчих заходів 3 мінімізації загроз національній інформаційній інфраструктурі. В пар- 
ламенті функціонує комітет з розвідки та безпеки, який вивчає діяльність адміністрації та витрати відповідних управлінь. Цей комітет щороку подає доповіді прем’єр-міністру. Існує також міністерський комітет 3 розвідувальних служб (Ministerial Committee on the Intelligence Services), який очолюється прем'єр-міністром і є однією 3 найвищих рад 3 питань безпеки та розвідки, котра має право контролювати виконання рішень відповідними управліннями [2].

Не менш поважним є Офіційний комітет Кабінету міністрів з питань безпеки (Cabinet Official Committee on Security), який контролює діяльність спецслужб, встановлює пріоритети національної безпеки, розподіляє їх між відомствами й управліннями, а також надає інформацію і поради міністру Кабінету міністрів, що відповідає за внутрішню безпеку країни. До цього комітету входять керівники Скарбниці, Міністерства закордонних справ, Міністерства внутрішніх справ, Міністерства оборони та інші посадовці [2].

Нарешті, Комітет з розвідки і безпеки (The Intelligence and Security Committee (ISC)), до якого входять дев'ять парламентарів за призначенням прем'єр-міністра після консультацій з лідером опозиції. Цей комітет контролює витрати й результати роботи спецслужб та інших структур, відповідальних за безпеку. Щороку комітет подає доповіді прем'єр-міністру, а той передає доповідь парламенту [2].

Що стосується Франції. При президентові діє Вища рада оборони як координаційноконсультативний орган державного управління силами оборони, що розробляє і надає президентові обгрунтовані рекомендації з питань реалізації воєнної політики і військового будівництва з урахуванням сучасних концептуальних підходів до вирішення певних питань [10].

Що стосується РП. У РП система керівництва та управління обороною поєднує в собі підсистеми управління законодавчих, виконавчих та суто військових структур. Президент РП та Рада Міністрів РП як органи виконавчої влади є головними органами керівництва обороною країни, які виконують свої завдання відповідно до Конституції та законодавства РП Президент РП здійснює загальне керівництво усіма державними структурами в галузі внутрішньої та зовнішньої безпеки країни і є Верховним Головнокомандувачем ЗС РП [18].

В РП є РНБ (Rada Bezpieczecstwa Narodowego) створена відповідно до Статті 135 Конституції РП: “Дорадчим органом Президента РП з питань зовнішньої і внутрішньої національної безпеки є РНБ”. В рамках РНБ створено Бюро національної безпеки (БНБ), яке виконує функції секретаріату Ради, тобто організовує її роботу й оцінює ситуацію [2].
РНБ - конституційний орган, навіть в реальному житті виступає лише як комісія найвищих посадовців держави $з$ питань державної безпеки. Натомість іiі “апарат" - БНБ, засноване 2002 року, реально набуває рис "державного аналітичного центру” (think tank), який, згідно з указом президента РП від 17 грудня 2004 року "Про питання організації Бюро національної безпеки”, забезпечує президента інформацією та сприяє тому, щоб президент міг повноцінно виконувати свої конституційні функції з питань безпеки і оборони. Детально ж завдання БНБ розписані стосовно його відділів: кабінету директора БНБ, департаменту керівництва президента РП збройними силами, департаменту обслуговування РНБ, відділу аналізу, відділу управління в умовах кризи. Кожна структура виконує свої чітко окреслені функції. Так, Кабінет директора БНБ забезпечує: організаційне обслуговування керівництва Бюро; співпрацю з урядом 3 питань безпеки; організацію міжнародних зв'язків Бюро; організацію надходження інформації до Бюро, тощо [2].

Вперше поняття СЗНБ було конкретизоване у Стратегії національної безпеки, прийнятій у листопаді 2007 р. [3].

Під СЗНБ розуміється внутрішньо координована сукупність “відповідальних за безпеку, згідно 3 Конституцією РП та відповідними законами, органів та установ, що належать до законодавчої, виконавчої та судової влади (зокрема, парламент, президент РП, Рада міністрів і центральні органи урядової адміністрації). Важливими його елементами є Збройні сили та урядові структури, зобов'язані запобігати і протидіяти зовнішнім загрозам, забезпечувати громадський порядок, проводити рятувальні заходи та захист населення і майна у надзвичайних ситуаціях, а також органи самоврядування та інші юридичні особи, включаючи підприємців, які створюють промислово-оборонний потенціал”[19].

Міністр національної оборони РП реалізує повноваження Президента РП у сфері керівництва ЗС РП у мирний час, здійснює керівництво діяльністю Міністерства національної оборони та ЗС РП безпосередньо та через заступників Міністерства національної оборони, начальника Генерального штабу РП, генерального командувача видів ЗС й оперативного командувача видів 3С [18].

Міністерство національної оборони РП є найвищим державним органом РП у сфері оборони, який керує діяльністю ЗС РП, готує проекти, які стосуються організації оборони держави [10].

Проте потрібно враховувати і те, що РП, будучи членом НАТО, має можливість зосереджуватися на розвитку лише окремих спроможностей військ (сил) відповідно до планів НАТО [10].

В [10] зазначається, що в рамках організаційноштатних заходів РП розформувала командування 
видів своїх збройних сил, створивши на їх основі Генеральне командування видів, та переформувала Генеральний штаб в орган стратегічного планування, координації та контролю. Після переходу на нову систему управління і керівництва почали з'являтися ознаки ii недосконалості та проблемні питання, пов'язані з новим порядком функціонування та життєдіяльності військ (сил). Виявилося, що у запровадженій системі управління і керівництва Війська Польського не враховано одного з головних принципів військового управління - наявності єдиного центру управління, наділеного відповідними повноваженнями та відповідальністю [10].

Намагаючись виправити ситуацію, у Польщі були змушені ухвалити закон, що передбачає призначення Головнокомандувача ЗС РП на воєнний час, але цим законом не передбачено вирішення решти проблем. Польща змушена була розробляти плани реформування загальної системи управління і розглянути можливість повернення Генеральному штабу Війська Польського ролі єдиного органу військового управління та формування органів управління, подібних до колишніх командувань видів збройних

сил [10].

Що стосується Туреччини. РНБ Туреччини було сформовано законом №2945 від 9 листопада 1983 року відповідно до конституції 1982 року. Саме ця конституція визначила, що головує в РНБ президент, до неї входять також прем'єр-міністр, начальник Генерального штабу, Міністр оброни, Міністр внутрішніх справ, Міністр зовнішніх справ, начальник наземних військ, начальник морських військ, начальник повітряних військ та генеральний начальник жандармерії. При необхідності на засідання РНБ можуть запрошуватися й інші посадовці [2].

В липні 2004 року парламент ухвалив низку законів, які зменшили роль військових у житті країни, в тому числі й в РНБ. Цей орган перестав бути частиною виконавчої гілки влади і реально перетворився на іiі секретаріат, адміністрацію. Згідно з цією реформою, вперше за всю історію РНБ їі секретаріат очолила цивільна особа [2].

Що стосується Японії. Система забезпечення державної безпеки й оборони сучасної Японії особлива $з$ огляду на те, що держава не має офіційно національних збройних сил. Проте в інституційному апараті держави функціонує Міністерство оборони, яке адмініструє діяльність Сил Самооборони держави (фактично, Сили Самооборони виконують функції Збройних Сил, хоча офіційно військом не називається). Показовим є те, що службовці Сил Самооборони не мають статусу військовослужбовців і формально вважаються державними службовцями. В управлінському відношенні, органами оперативного управління силами оборони $є$ командування округів, яких у Японії нараховується 5 (п’ять). Командувачі округів підпорядковуються прем'єрміністру держави, який відповідальний за вирішення питань у сфері національної безпеки і оборони [4].

Сили Самооборони формуються з тріади основних елементів - сухопутних, морських та повітряних сил [20].

За розрахунками спеціалістів, система адміністрування оборони Японії спрямована на оперативне відвернення морської, сухопутної і повітряної загрози вторгнення i порушення державного кордону. Враховуючи те, що Японія є острівною державою, наявного оборонного потенціалу достатньо для виконання відповідних завдань [4].

Враховуючи тісні інтегративні зв'язки системи оборони й системи забезпечення національної безпеки, японська система служб безпеки є більш складною і розгалуженою, аніж система оборони. Це зумовлено тим, що Японія є одним зі світових лідерів інноваційного ринку технологій, концентрує великий обсяг інтелектуального потенціалу та має значний обсяг зовнішньоекономічних зв'язків. Через це соціальна, безпекова і виробнича інфраструктура Японії є об’єктом уваги іноземних спецслужб [4].

Що стосується КНР. Китай за останні десятки років створив власну національну модель адміністрування національної безпеки і оборони, яка є ефективною, оригінальною і модель якої навряд можна запозичити іншій державі [4].

Основним суб'єктами військового управління, до компетенції яких належить керівництво силами безпеки і оборони республіки, є Міністерство державної безпеки КНР та Центральна військова рада KHP [4].

Що стосується Південної Кореї. Після війни 3 Північною Кореєю у 1953 р., коли питаннями зовнішньої оборони держави формально опікувалася ООН, Південна Корея і США підписали двосторонню угоду про взаємну оборону. Після цього формування власного сектора безпеки й оборони Південної Кореї відбувалося, фактично, фахівцями США. У листопаді 1954 р. Південна Корея і США підписали Угоду про військову та економічну допомогу. Згідно з угодою, тодішні оперативні командні повноваження було замінено повноваженнями оперативного управління [21].

Пізніше, у 1970-х роках остаточно було сформовано спільну із США політику адміністрування безпеки й обороноздатності. Ї̈і сутність полягає у тому, що Південна Корея на сьогодні утримується від прийняття самостійних стратегічних рішень у міжнародних відносинах, які формуються навколо регіональної безпеки на Корейському півострові. Крім того, Південна Корея практично не має системи національної розвідки, тому у цій сфері залежить від компетенції відповідних органів США в галузі 
розвідки та контролю над безпековою ситуацією. Відповідно, адміністрування забезпечення розвідувальної діяльності в аспекті національної безпеки здійснюється в обмежених формах і зводиться до організації навчання військового персоналу, організаційне супроводження діяльності американських військових підрозділів, розвитку і впровадження інноваційних технологій та новітніх технологічних розробок у систему національної безпеки й обороноздатності [4].

Південна Корея активно розвиває власні збройні сили, які доволі чисельні. Війська поділяються на діючі та резервні. У структурі збройних сил виокремлюються сухопутні війська, військовоморський флот, військово-повітряні сили, корпус морської піхоти. Особливий інтерес викликає підрозділ армії США, у якому проходить службу 1800 чоловіків - громадян Кореї "Katusa". Керівництво армією і підрозділами здійснюється за американським зразком [4].

Провідні західні держави мають дві базові моделі розподілу повноважень основних інститутів оборони, які умовно можна назвати американською та європейською. Тут фактично можна говорити про “президентську” та “парламентську” моделі. В обох із них усі військові функції, у тому числі військова розвідка та військова контррозвідка, покладені на міністерство оборони. Таке поєднання повноважень супроводжується розвинутою системою цивільного контролю над органами військового управління [10].

Відмінності цих двох моделей торкаються розподілу повноважень і підпорядкування правоохоронних органів та спецслужб [10].

Іншою важливою особливістю зарубіжних країн $€$ зміцнення координуючих структур та інтеграція силових інститутів [10].

Подвійні посади, такі як “керівник координуючого органу -помічник або радник політичної особи”, відповідальної за національну безпеку, зараз створюють у багатьох країнах НАТО. Це дає змогу значно збільшити керованість та координованість сектору безпеки і оборони, підвищити ефективність прийняття і реалізації безпекових та оборонних рішень [10].

Важливим напрямом підвищення ефективності прийняття та реалізації рішень у секторі безпеки i оборони є інтеграція структур управління і забезпечення їх зв'язку з політичним керівництвом. Ідея інтеграції полягає в тому, що найвищий неполітичний державний посадовець у відповідній силовій структурі $є$ радником демократично обраного або призначеного на посаду політика, уповноваженого командувати й управляти. Наприклад, у США та західноєвропейських країнах начальник генерального штабу (найвищий військовий посадовець) не входить до складу командування та управління, а є радником цивільного міністра оборони [10].
Протягом останніх років у США та Канаді, більшою мірою, а в європейських країнах - меншою відбуваються істотні трансформації в системі управління силовими інститутами, спричинені кардинальною зміною структури сучасних загроз. У нових доктринальних документах 3 національної безпеки, прийнятих у багатьох країнах після терористичних нападів на США, Іспанію та Велику Британію, визначено, що терористи, особливо оснащені зброєю масового ураження, є основним джерелом загроз [10].

Особливістю нових доктринальних документів країн НАТО є визнання їх фундаментальної невизначеності щодо місця, часу та форми прояву загроз. Необхідність точної та своєчасної ідентифікації сучасних загроз $є$ основною вимогою нового етапу реформ у секторі оборони провідних країн. В англосаксонських країнах (США, Канаді, Великій Британії та Австралії), які приділяють особливу увагу розвитку силових інститутів, із різними назвами були створені спеціальні центри оцінювання загроз, уповноважені інтегрувати інформацію з усіх джерел і доводити іiі до необхідних адресатів, починаючи 3 найвищого керівництва, а також оголошувати загальний рівень готовності до нападу, відповідно до якого повинні діяти всі державні інститути [10].

Що стосується України. Законодавством України [22] визначаються та розмежовуються повноваження державних органів у сферах національної безпеки і оборони, створюється основа для інтеграції політики та процедур органів державної влади, інших державних органів, функції яких стосуються національної безпеки і оборони, сил безпеки і СО, визначається система командування, контролю та координації операцій сил безпеки і СО, запроваджується всеосяжний підхід до планування у сферах національної безпеки і оборони, забезпечуючи у такий спосіб демократичний цивільний контроль над органами та формуваннями СБіО.

В [22] також визначено, що СБіО - система органів державної влади, Збройних Сил України (3С України), інших утворених відповідно до законів України військових формувань, правоохоронних та розвідувальних органів, державних органів спеціального призначення з правоохоронними функціями, сил цивільного захисту, оборонно-промислового комплексу України, діяльність яких перебуває під демократичним цивільним контролем і відповідно до Конституції та законів України за функціональним призначенням спрямована на захист національних інтересів України від загроз, а також громадяни та громадські об'єднання, які добровільно беруть участь у забезпеченні національної безпеки України.

СБіО складається з чотирьох взаємопов'язаних складових: сили безпеки; СО; обороннопромисловий комплекс; громадяни та громадські 
об'єднання, які добровільно беруть участь у забезпеченні національної безпеки [22].

Складові СБіО (СО), які відповідно до сформованих сценаріїв, сил і засобів, які до цього залучаються здійснюють заходи щодо реагування на кризові ситуації.

3 метою інформаційно-аналітичної підтримки прийняття рішень створюється мережа СЦ під загальною координацією Головного СЦ України.

Поряд 3 цим, існують національні та галузеві системи, сфокусовані на протидії певним видам загроз, включаючи забезпечення готовності до кризового управління у випадку реалізації таких загроз. У рамках функціонування цих систем передбачені механізми обміну інформацією (у т.ч. через спеціально створені з цією метою СЦ). Прикладами таких систем і підсистем можуть бути [23]:

1. Сдина система запобігання, реагування та припинення терористичних актів і мінімізації їх наслідків;

2. Державна система фізичного захисту;

3. Єдина державна система цивільного захисту, до якої, серед інших, включений ряд підсистем (наприклад, підсистема безпеки об'єктів ядерної енергетики);

4. Єдина державна система запобігання і реагування на надзвичайні ситуації техногенного та природного характеру та деякі інші.

Поряд 3 цим, відповідно до [24] визначені завдання щодо побудови додаткових СЦ держави, а саме:

Що стосується створення системи національних стратегічних комунікацій:

- затвердження та постійне оновлення стандартів і методик проведення моніторингу засобів масової інформації та збору аналітичних даних;

- створення мережі СЦ у державних органах (в межах системи національних стратегічних комунікацій) та інше;

щуо стосується створення Національної системи стійкості:

- формування єдиної нормативно-правової бази у сфері планування та реагування на кризові ситуації та загрози з метою забезпечення координації дій державних органів у таких ситуаціях;

- законодавче закріплення регулярного проведення багаторівневої національної оцінки ризиків i загроз у сфері національної безпеки та визначення органу державної влади, який забезпечуватиме ведення Національного реєстру загроз.

- забезпечення достатніми організаційнотехнічними та фінансовими спроможностями суб'єктів забезпечення національної стійкості для ефективного задоволення потреб населення у разі виникнення кризових ситуацій.

Що стосується створення державної системи захисту критичної інфраструктури:

- створення мережі СЦ моніторингу та аналізу ризиків для запобігання загрозам для об'єктів критичної інфраструктури, що досягається виконанням таких пріоритетних завдань: формування нормативно-правової бази для функціонування СЦ; творення ефективної системи обміну інформацією між суб'єктами та об'єктами державної системи захисту критичної інфраструктури для прогнозування можливих загроз та запобігання їм; $\mathrm{CO}$ :

Що стосується створення системи управління

- розбудова спільної структури командування, контролю та координації СО на стратегічному, оперативному та тактичному рівнях, сумісну із системами військового керівництва держав - членів НАТО, що досягається виконанням таких пріоритетних завдань: завершення уніфікації системи стандартів та процедур планування, що застосовуються силами оборони; завершення унормування функцій, завдань і повноважень посадових осіб на стратегічному та оперативному рівнях; набуття Командуванням об'єднаних сил ЗС України повних оперативних спроможностей ефективно керувати силами та засобами СО, переданими в оперативне підпорядкування;

- створення Національної телекомунікаційної мережі з можливістю надання сучасних телекомунікаційних послуг;

- створення автоматизованої системи оперативного (бойового) управління, зв'язку, розвідки та спостереження складових СБіО відповідає стандартам, доктринам і рекомендаціям НАТО, що досягається виконанням пріоритетного завдання із забезпечення відповідності стандартам, доктринам i peкомендаціям HATO автоматизації системи C4ISR на оперативному і тактичному рівнях для видів, окремих родів військ (сил) 3С України та інших складових СБіО;

- інтеграція системи управління оборонними ресурсами 3 автоматизованою системою оперативного (бойового) управління, зв'язку, розвідки та спостереження складових СО, що досягається виконанням пріоритетного завдання 3 упровадження компоненти системи C4ISR;

- нарощення можливостей СЦ складових СБіО, що досягається виконанням пріоритетного завдання зі створення системи СЦ складових СБіО для оперативного прийняття рішень у сфері оборони;

Що стосується створення умови для безпечного функиіонування кіберпростору та його використання в інтересах особи, суспільства і держави:

- створення єдиної мережі галузевих СЦ кібербезпеки, що здатна забезпечити оперативне реагування на кіберзагрози на рівні, який відповідає стандартам НАТО, що досягається виконанням таких пріоритетних завдань: визначення сфери відповіда- 
льності державних органів, залучених до створення єдиної мережі галузевих СЦ кібербезпеки, та затвердження концепції створення такої мережі; забезпечення спроможностей СЦ забезпечення кібербезпеки Служби безпеки України та Державного центру кіберзахисту Державної служби спеціального зв'язку та захисту інформації України, інших галузевих центрів кібербезпеки та суб'єктів забезпечення кібербезпеки щодо надання Національному координаційному центру кібербезпеки інформації про кібератаки і кіберінциденти, здійснення обміну інформацією в режимі реального часу та співпраці 3 іноземними партнерами.

\section{Висновки}

Таким чином в країнах світу при побудові СЗНБ суттєвий вплив здійснюють: історичні традиції, географічне положення та розмір країн (насе- лення), укладені міжнародні договори. В цілому структура СЗНБ носить однакові світові тенденції та по функціональному призначенню умовно поділяється на СО і сили безпеки. Для підготовки та прийняття рішень в кризових ситуаціях використовують СЦ (інформаційно-аналітичні підрозділи).

Враховуючи, що відповідно до вимог нормативних документів існує потреба створення СЦ в різних сферах діяльності держави та враховуючи стан створення систем реагування на кризові ситуації в Україні доцільно створити, на базі існуючої мережі СЦ, єдину державну ієрархічну мережу СЦ з елементами (складовими), які відповідають за відповідні напрямки (сфери) діяльності держави за координуючої ролі Головного СЦ України.

В подальшому дослідження будуть зосереджені на створенні моделі державної системи управління СО в кризових ситуаціях.

\section{Список літератури}

1. Мосейко А. Г., Негодченко В. О. Досвід Сполучених штатів Америки щодо публічного адміністрування в сфері національної безпеки. Право і суспільство. 2019. № 4. С. 323-329. https://doi.org/10.32842/2078-3736-2019-4-48.

2. Біденко А. Законодавчі аспекти управління національною безпекою за рубежем. Політичний менеджмент. 2006. № 3. C. $132-140$.

3. Концептуальні засади розвитку системи забезпечення національної безпеки України: аналіт. доп. / Резнікова О. О. та ін. Київ : НІСД, 2015. 58 c. URL: http://www.niss.gov.ua (дата звернення: 19.06.2021).

4. Мельник С. Адміністрування національної безпеки й оборони органами військового управління у державах Азії (на прикладі Японії, Китаю, Південної Кореї). Актуальні проблеми правознавства. 2019. № 2(18). С. 55-60.

5. Кобко Є. В., Даугулє А. В. Досвід публічно-правового забезпечення національної безпеки країни Європи і США та шляхи його запозичення для України. Науковий вісник публічного та приватного права. 2018. № 4(2). С. $186-190$.

6. Труш О. О., Гудима О. П., Новік І. С. Інформаційно-аналітичні засоби забезпечення державного управління у провідних країнах світу: досвід для України. Теорія та практика державного управління. 2014. № 3(46). С. $287-295$.

7. Гудима О. П. Національний досвід створення ситуаційних центрів в органах державної влади. Публічне адміністрування та національна безпека. 2020. № 8(16). С. 104-111. https://doi.org/10.25313/2617-572X-2020-8-6446.

8. Situational Center as an element of the state management system in counteracting hybrid threats. Current issues of military specialists training in the Security and Defence Sector under conditions of hybrid threats: monograph / Hudyma O., Pacek B., Pievtsov H., Syrotenko A. Warsaw : Wydawnictwo Instytutu Bezpieczeństwa i Rozwoju Międzynarodowego, 2021. P. 58-65. URL: https://instytutbirm.pl/wp-content/uploads/2021/03/Monografia_mm1.pdf.

9. Труш О. О., Гудима О. П., Кошкін О. А. Підвищення ефективності прийняття державно-управлінських рішень у сфері національної безпеки в умовах надзвичайних (кризових) ситуацій. Міжнародний науковий журнал. 2016. № 11(21), том 1. C. 19-22. URL: http://www.geosphere.com/ ESR.html (дата звернення: 19.06.2021).

10. Сектор безпеки і оборони України : стратегічне керівництво та військове управління : монографія / Саганюк Ф. В. та ін., за ред. Руснака І. С. Київ : ЦЗ МО та ГШ ЗС України, 2018. 230 с.

11. Бессонова М. Стратегії національної безпеки США пост-біполярної епохи : головні регіональні виміри загроз американським інтересам. Гілея : науковий вісник. 2013. № 75. С. 141-144.

12. Пелих А. О. Концепції застосування військової сили в системі державної політики національної безпеки США. Державне управління: теорія та практика. 2013. № 2. С. 62-68.

13. Вонсович О. С. Стратегія національної безпеки США 2017 р. : нові підходи щодо боротьби із пріоритетними викликами та загрозами. Гілея : науковий вісник. 2018. № 129. С. 332-334.

14. Ситник Г. П. Концептуальні засади забезпечення національної безпеки України : навч. посіб. Ч. 3 : Державна політика та основи стратегічного планування забезпечення національної безпеки. Київ : НАДУ, 2010. С. 55-61.

15. Treaty on European Union - Maastricht Treaty. URL: http://europa.eu/eulaw/decision-making/ treaties/pdf/treaty_on_european_union/treaty_on_european_union_en.pdf (accessed: 19.06.2021).

16. Давиденко О. І. Правовий статус Верховного представника $Є С$ із закордонних справ та безпекової політики. Держава і право. Юридичні і політичні науки. 2013. № 60. C. 415. URL: http://nbuv.gov.ua/j-pdf/dip_2013_60_68.pdf. (дата звернення: 19.06.2021).

17. National Security Decision-Making Structures and Security Sector Reform / Bearne Susanna, Oliker Olga, O'Brien Kevin A., Rathmell Andrew. RAND Europe : web site. URL: https://www.rand.org/pubs/technical_reports/TR289.html (accessed: 19.06.2021).

18. National Intelligence Machinery. URL: https://assets.publishing.service.gov.uk/government/ uploads/system/uploads/attachment_data/file/250868/0114301808.pdf (accessed: 19.06.2021).

19. Strategia bezpieczeństwa narodowego Rzeczypospolitej Polskiej- 2007 : веб-сайт. URL: http://www.koziej.pl/files/SBN_RP.pdf. (дата звернення: 19.06.2021). 
20. Японія - країна вранішнього сонця. Національна безпека : веб-сайт. URL: https://sites.google.com/site/yponiaorlova/home/6-politika/nacionalna-bezpeka (дата звернення: 19.09.2021).

21. Перелигін Є. Корейські уроки політики безпеки. ZN.UA : веб-сайт. URL: https://dt.ua/internal/koreyskiurokipolitiki-bezpeki-_.html (дата звернення: 19.06.2021).

22. Про національну безпеку України: Закон України від 21 червня 2018 р. № 2469-VIII (із змінами) : веб-сайт. URL: https://zakon.rada.gov.ua/laws/show/2469-19\#Tеxt (дата звернення: 19.06.2021).

23. Кондратов С. І. Про забезпечення координації дій, взаємодії та обміну інформацією при створенні державної системи захисту критичної інфраструктури. Київ : НІСД, 2018. 30 c. URL: http://old2.niss.gov.ua/content/articles/files/21grudnya-2018-Anal_tichnaDopov_dKDVO_priZK_-v_dkorig-format-bf848.pdf (дата звернення: 19.06.2021).

24. Про Річну національну програму під егідою Комісії Україна - НАТО на 2021 рік: Указ Президента України від 11 травня 2021 року № 189/2021 : веб-сайт. URL: https://www.president.gov.ua/documents/1892021-38845 (дата звернення 19.06.2021).

Надійшла до редколегії 01.06.2021

Схвалена до друку 13.07.2021

\section{Відомості про авторів:}

\section{Гудима Олег Петрович}

кандидат технічних наук старший науковий співробітник докторант Центру воєнно-стратегічних досліджень

Національного університету оборони

України ім. І. Черняховського,

Київ, Україна

https://orcid.org/0000-0002-3494-8583

\section{Information about the authors:}

\section{Oleh Hudyma}

Doctor of Philosophy Senior Researcher

Doctoral Student of the Center for Military and Strategic

Studies of the National Defence University of Ukraine named after Ivan Chernyhovskij,

Kyiv, Ukraine

https://orcid.org/0000-0002-3494-8583

\section{МЕЖДУНАРОДНЫЙ ОПЫТ ПОСТОРЕНИЯ СИСТЕМ ОБЕСПЕЧЕНИЯ НАЦИОНАЛЬНОЙ БЕЗОПАСНОСТИ. ВЫВОДЫ ДЛЯ УКРАИНЫ}

О.П. Гудыма

На протяжении 30 лет независимости Украины продолжаются работы по построению системы обеспечения национальной безопасности государства (сектора безопасности и обороны, сил обороны). С изданием новой редакции Закона Украинь “О национальной безопасности Украины” " изменилась структура руководящих документов государства. На сегодняшний день продолжается этап разработки соответствуюших нормативных документов иентральными органами исполнительной власти, выполняющих задачи в сфере национальной безопасности и обороны. При формировании нормативно-правовой базы государства целесообразно учесть опыт построения систем обеспечения национальной безопасности стран мира. В статье проанализирован опыт Соединенных Штатов Америки, Канады, стран Евроnы, Китайской народной республики, Туриии, Японии, Южной Кореи. На основе проанализированного опыта разработаны предложения по совершенствованию системы обеспечения начиональной безопасности Украины (сектора безопасности и обороны, сил обороны) и государственной системы управления силами обороны в кризисных ситуациях.

Ключевые слова: начиональная безопасность, нормативно-правовая база, силь обороны, международный опыт, государственная система управления.

\section{INTERNATIONAL EXPERIENCE IN BUILDING NATIONAL SECURITY SYSTEMS. CONCLUSIONS FOR UKRAINE}

\section{O. Hudyma}

During the 30 years of Ukraine's independence, work has been underway to build a system for ensuring the national security of the state (security and defense sector, defense forces). With the publication of a new version of the Law of Ukraine "On National Security of Ukraine", the structure of governing documents of the state has changed. At present, the stage of elaboration of the relevant normative documents by the central executive bodies, which perform tasks in the field of national security and defense, is underway. When forming the regulatory framework of the state, it is advisable to take into account the experience of building national security systems of the world. The article analyzes the experience of the USA, Canada, Europe, China, Turkey, Japan, and South Korea. Leading Western countries have two basic models of division of powers of the main defense institutions, which can be called American and European. These are in fact "presidential" and "parliamentary" models. In both, all military functions, including military intelligence and military counterintelligence, are vested in the Ministry of Defense. This combination of powers is accompanied by a developed system of civilian control over the military authorities. Dual positions, such as "head of the coordinating body-assistant or adviser to a national security official", are now being created in many NATO countries. This allows to significantly increase the controllability and coordination of the security and defense sector, increase the efficiency of making and implementing security and defense decisions. In general, the structure of national security systems has the same global trends and is functionally divided into defense forces and security forces. Situation centers (information and analytical units) are used to prepare and make decisions in crisis situations. Given that in accordance with the requirements of normative documents of Ukraine there is a need to create situational centers in various spheres of state activity and taking into account the state of crisis response systems in Ukraine it is advisable to create a single state hierarchical network of situational centers with elements, which are responsible for the relevant areas (spheres) of the state in the coordinating role of the Main Situational Center of Ukraine.

Keywords: national security, regulatory framework, defense forces, international experience, public administration system. 